\title{
Lectin histochemical aspects of the ovarian lamellae epithelium of Genypterus blacodes (Schneider, 1801) ${ }^{1}$
}

\author{
Alcira O. Díaz ${ }^{2 *}$, Roberto O. Freijo ${ }^{2}$, Alicia M. García ${ }^{2,6}$, Enrique L. Portiansky ${ }^{3,6}$, \\ Claudio G. Barbeito ${ }^{4,6}$ and Gustavo J. Macchi ${ }^{5,6}$
}

\begin{abstract}
Díaz A.O., Freijo R.O., García A.M., Portiansky E.L., Barbeito C.G. \& Macchi G.J. 2012. Lectin histochemical aspects of the ovarian lamellae epithelium of Genypterus blacodes (Schneider, 1801). Pesquisa Veterinária Brasileira 32(6):547-552. Instituto de Investigaciones Marinas y Costeras (IIMyC), Departamento de Biología, FCEyN, CONICETUniversidad Nacional de Mar del Plata, Funes 3250, 3ํㅜ piso, (7600) Mar del Plata, Argentina. E-mail: adiaz@mdp.edu.ar

The composition and distribution of the glycoconjugates (GCs) secreted by the epithelium of ovarian lamellae with reference to the reproductive biology of Genypterus blacodes (Schneider, 1801) through lectin histochemistry is here discussed. In this species, the epithelial cells that line the ovarian cavity presented sharp morphological variations along the reproductive cycle related to the mucus secretion that accompanies oocyte maturation. During spawning season, residues of mannose and $\mathrm{N}$-acetylglucosamine were detected in the glycocalyx of those cells using lectinhistochemistry. $\mathrm{N}$-acetylgalactosamine and fucose were also observed in the same zone. The greatest variations in the lectinhistochemical pattern were found in the apical cytoplasm composition in comparison to the basal zone of the cells. The results of the present study were discussed by comparing their possible functional implications.
\end{abstract}

INDEX TERMS: Genypterus blacodes, glycoconjugates, histochemistry, lectins, ovary.

RESUMO.- [Padrão de reação lectino-histoquímico do epitélio laminar ovariano em Genypterus blacodes (Schneider, 1801).] A composição e distribuição dos glicoconjugados (GCs) secretado pelo epitélio do ovário de lamelas com referência à biologia reprodutiva de Genypterus blacodes (Schneider, 1801) através da histoquímica com lectinas é aqui discutida. Nesta espécie, as células epiteliais que reves-

\footnotetext{
${ }^{1}$ Received on July 16, 2011.

Accepted for publication on February 22, 2012.

${ }^{2}$ Instituto de Investigaciones Marinas y Costeras (IIMyC), Departamento de Biología, FCEyN, CONICET- Universidad Nacional de Mar del Plata, Funes 3250,3 o piso, (7600) Mar del Plata, Argentina. *Corresponding author: adiaz@mdp.edu.ar

${ }^{3}$ Instituto de Patología, Facultad de Ciencias Veterinarias, Universidad Nacional de La Plata (UNLP), 60 y 118, La Plata (1900), Buenos Aires, Argentina.

${ }^{4}$ Cátedra de Histología y Embriología, Facultad de Ciencias Veterinarias, Universidad Nacional de La Plata (UNLP), 60 y 118, La Plata (1900), Buenos Aires, Argentina.

${ }^{5}$ Instituto Nacional de Investigación y Desarrollo Pesquero (Inidep), Paseo Victoria Ocampo 1, Mar del Plata, General Pueryrredon (7600), Buenos Aires, Argentina

${ }^{6}$ Consejo Nacional de Investigaciones Científicas y Técnicas (Conicet), Buenos Aires, Argentina.
}

tem a cavidade do ovário apresentou acentuada variação morfológica ao longo do ciclo reprodutivo relacionados com a secreção de muco que acompanha a maturação do oócito. Durante a época de desova, de resíduos de manose e $\mathrm{N}$-acetilglicosamina foram detectados no glicocálix dessas células usando histoquímica de lectinas. $\mathrm{N}$-acetilgalactosamina e fucose também foram observados na mesma zona. As maiores variações no padrão de lectinas foram encontradas na composição do citoplasma apical, em comparação com a zona basal das células. Os resultados do presente estudo foram discutidos, comparando as suas possíveis implicações funcionais.

TERMOS DE INDEXAÇÃO: Genypterus blacodes, glicoconjugados, histoquímica, lectinas, ovário.

\section{INTRODUCTION}

Genypterus blacodes (Schneider, 1801) (Pisces, Ophidiidae), the pink cuskeel, is one of two species of economic importance in this genus, captured by commercial fishing in the Southwest Atlantic. This species is distributed both in the Pacific and Atlantic seawaters of South America. In the Pacific coast, it appears south of 290 55' S (Coquimbo), while in the Southwest Atlantic, G. blacodes inhabits from $34^{\circ} \mathrm{S}$ to 
$55^{\circ}$ S. Populations of $G$. blacodes can also be found in New Zealand's waters (Louge et al. 1992, Cousseau \& Perrota 2000). Adults exhibit a demersal behaviour and they are usually found at depths between 45 to $350 \mathrm{~m}$. In Patagonian coastal waters, from $41^{\circ} \mathrm{S}$ to $45^{\circ} \mathrm{S}$ (Province of Chubut, Argentina), the reproductive activity of the species occurs mainly during summer (Louge et al. 1992).

G. blacodes possess ovaries of the cystovarian type with numerous crests or lamellae of connective tissue covered by a simple plane epithelium layer, namely the epithelium of ovarian lamellae. In these crests, oocytes at different developmental stages were observed (Louge et al. 1992, Machinandiarena et al. 1998). The epithelium of the ovarian lamellae borders upon the ovarian lumen and shows seasonal variations in its morphological features during the reproductive cycle in different teleostean species (Yoneda et al. 1998 a and b). Furthermore, the epithelium of ovarian lamellae is implicated in the formation of ovarian fluid in the majority of the teleost species (Freijo et al. 2009). This fluid apparently has different functions: preservation of fertile eggs (Lahnsteiner 2007), promotion of sperm motility (Koya et al. 2002), lubrication at spawning (Munehara 1989) and formation of egg masses (Mansour et al. 2009). The ovarian fluid of $G$. blacodes is viscous and during the spawning season it shows large amounts of mucus filling the ovarian lumen, a characteristic that differentiates this species from most of the Southwest Atlantic teleosts (Freijo et al. 2009).

Few studies have centred on the chemical composition of mucus secreted by teleost ovaries. Glycoconjugates (GCs) are the main constituents of mucous secretions in teleosts (Mittal et al. 2002, Arellano et al. 2004, Díaz et al. 2005, 2008).

In spite of its great economic relevance among species captured in the Argentinean Sea, knowledge on reproductive biology of $G$. blacodes is limited. Machinadiarena et al. (1998) determined that this species is a batch spawner, with low fecundity and a high spawning frequency. In a recent study, Freijo et al. (2009) have demonstrated that GCs with oxidizable vicinal diols groups, sialic acid with or without 0 -acyl substituent's, $\mathrm{O}$-acyl sugars, neutral sugars and GCs with carboxyl and sulphate groups are produced by the cells of the epithelium of the ovarian lamellae of $G$. blacodes during spawning. These authors have reported morphological changes in the epithelium of ovarian lamellae associated with a secretory activity of mucus during the spawning season. This characteristic suggests that $G$. blacodes could release egg masses covered with mucus, although not individually as in other species with external fertilisation mechanisms (Freijo et al. 2009).

Lectins, which are either carbohydrate binding proteins or GCs of non-immune origin that agglutinate cells and precipitate GCs, are a valuable tool for detection and localisation of sugar sequences in oligosaccharide chains of GCs (Parillo et al. 2009). In the present work we characterized the sugar residue content of GCs in cells of the epithelium of ovarian lamellae of $G$. blacodes using lectins as histochemical probes.

\section{MATERIALS AND METHODS}

Forty female Genypterus blacodes were collected during two research trawl cruises carried out in San Jorge Gulf (45ㅇ $-47^{\circ} \mathrm{S}$, $65^{\circ}-67^{\circ} \mathrm{W}$ ) during January 1997 and March 1998. Ovaries were macroscopically examined on board for maturity staging and a diagnosis was made according to a 5-stage maturity scale: 1) immature, 2) developing, 3) spawning, 4) post-spawning, and 5) resting (Machinandiarena et al. 2003).

Ovaries from sampled individuals were removed immediately after capture, fixed by immersion in Bouin's fluid or $10 \%$ buffered formalin for light microscope studies. Samples were routinely processed and embedded in paraffin wax. Four $\mu \mathrm{m}$-thick histological sections were cut (Microtome 1512, Leitz Wetzlar) and prepared according to standard protocol. Biotinylated lectins were used to identify specific sugar residues of GCs. Lectin staining methodologies were done according to Gimeno et al. (1995). Paraffin sections mounted on slides coated with Poly-L-lisine (Sigma Diagnostics, St Louis, MO, USA) were deparaffinised with xylene and then incubated in $0.3 \% \mathrm{H}_{2} \mathrm{O}_{2}$ in methanol for $30 \mathrm{~min}$ at room temperature in order to block the endogenous peroxidase activity. Later, they were hydrated, washed in a phosphate-buffered saline (PBS) $0.01 \mathrm{M}, \mathrm{pH} 7.2$ solution and incubated for 30 minutes with biotinylated lectins. Biotinylated lectins were purchased from Vector Laboratories Inc, Burlingame, CA, USA. Afterwards, sections were washed again in PBS and subsequently treated with an ABC kit (Vectastain Elite PK 6200 Vector Laboratories Inc, Burlingame, CA, USA). After a new washing in PBS the reaction sites were revealed with diaminobenzidine tetrahydrochloride (DAB) (DAKO) $0.5 \mathrm{mg} / \mathrm{mol}$ in tris buffer $0.1 \mathrm{M}$, pH 7.2, plus $0.02 \% \mathrm{H}_{2} \mathrm{O}_{2}$. Each lectin was used at a $30 \mu \mathrm{g} / \mathrm{ml}$ dilution in PBS, except for PNA, which was applied at a concentration of $10 \mu \mathrm{g} / \mathrm{ml}$. Table 1 lists the seven lectins used in this study as well as their sources and their major sugar specificities.

Two types of controls were performed on sections: exposure to PBS instead of lectin test and exposure to lectins which had been pretreated for $1 \mathrm{~h}$ with the appropriate hapten sugars $(0.2$ $\mathrm{M}$ in PBS) at room temperature. Control sections completely abolished staining.

Authors' evaluation of staining intensities was based on subjective estimates by examination of two sections per sample of all the animals tested. The lectin binding intensity was visually graded as negative (0), weak (1), moderate (2) and strong (3).

\section{RESULTS}

The most significant changes were observed during the spawning stage, when epithelial cells become cube or column - shaped. The other maturity stages bear a simple squamous epithelium with no evident labelling with lectins. The lectinhistochemical pattern identified for the epithelial cells of the epithelium of the ovarian lamellae of $G$. blacodes at spawning stage is summarised in Table 2.

\section{Glycocalyx-cilia}

Intense reactions were observed when samples were incubated with lectins Con- A and WGA. Using the lectins DBA, SBA and UEA-1, the reaction was moderate in the same zone. Staining was weak when samples were incubated with PNA and RCA-1 (Fig.1).

\section{Cytoplasm}

A sharp polarity in the lectinhistochemical pattern of the cytoplasm was detected. The basal region reacted with none of the used lectins, while the apical region moderately reacted with Con-A and SBA. Labeling was weak with WGA, DBA y PNA, whereas no staining was eviden- 
Table 1. Carbohydrate binding specificity of lectins employed in this study

\begin{tabular}{lcl}
\hline \multicolumn{1}{c}{ Lectin } & Acronym & \multicolumn{1}{c}{ Specificity ${ }^{\text {a,b }}$} \\
\hline Canavalia ensiformis agglutinin & Con-A & $\alpha$-D-Man; $\alpha$-D-Glc \\
Triticum vulgaris agglutinin & WGA & $\beta$-D-GlcNAc; NeuNAc \\
Dolichos biflorus agglutinin & DBA & $\alpha$-D-GalNAc \\
Glycine maxi agglutinin & SBA & $\alpha$-D-GalNAc; $\beta$-D-GalNAc \\
Arachis hypogaea agglutinin & PNA & $\beta$-D-Gal $(\beta 1->3)$ D-GalNAc \\
Ulex europaeus agglutinin-I & UEA-I & $\alpha$-L-Fuc \\
Ricinus communis agglutinin-I & RCA-I & $\beta$-Gal
\end{tabular}

${ }^{a}$ Goldstein and Hayes (1978). ${ }^{\mathrm{b}}$ Fuc $=$ fucose; Gal =[ galactose; GalNAc = $\mathrm{N}$-acetylgalactosamine; Glc = glucose; GlcNAc = N-acetylglucosamine; Man = mannose; NeuNAc $=$ acetyl neuraminic acid $($ sialic acid $)$.

Table 2. Lectin staining pattern of the epithelium of ovarian lamellae of Genypterus blacodes at spawning stage

\begin{tabular}{lccccccc}
\hline & Con-A & WGA & DBA & SBA & PNA & RCA-1 & UEA-1 \\
\hline Glycocalyx- Cilia & 3 & 3 & 2 & 2 & 1 & 1 & 2 \\
Apical cytoplasm & 2 & 1 & 1 & 2 & 1 & 0 & 0 \\
Basal cytoplasm & 0 & 0 & 0 & 0 & 0 & 0 & 0
\end{tabular}

Staining intensity: 0 = negative; 1 = weak; 2 = moderate; 3 = strong. ced with RCA- 1 and UEA-1 in the supranuclear region of the epithelial cells (Fig.1).

\section{DISCUSSION}

Using lectinhistochemistry it was possible to establish the heterogeneity of GCs present in the cells of the epithelium of ovarian lamellae of Genypterus blacodes. Moreover, lectin histochemistry provided more detailed information on the specific localization of terminal and subterminal glucidic residues in the epithelium of ovarian lamellae of G. blacodes.

The oligosaccharide chains of GCs have been classified into two families: $\mathrm{N}$ - and $\mathrm{O}$ - linked oligosaccharides. The first group is characterized by a reducing terminal $\mathrm{N}$ - acetyl glucosamine (GlcNAc) N- glycosidically bound to asparagine. The 0- linked (mucin type) oligosaccharide classically contains a reducing terminal $\mathrm{N}$ - acetylgalactosamine (Gal NAc) linked 0- glycosidically to serine or threonine. These amino acid residues can also link fucose (Fuc), glucose
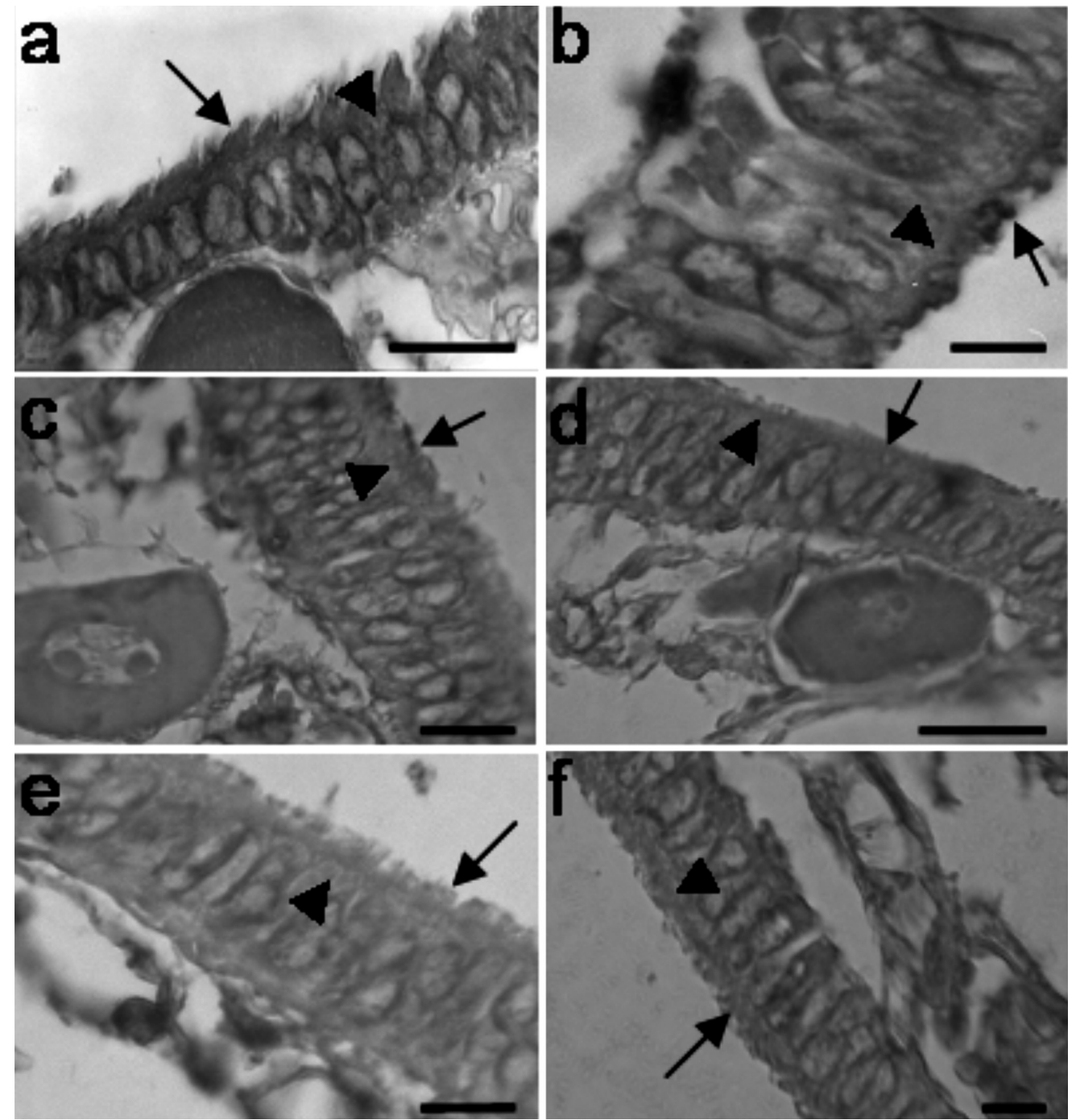

Fig.1. Lectin histochemistry of the ovarian lamellae epithelium of Genypterus blacodes. (a) Con A. Scale bar: $28 \mu \mathrm{m}$. (b) WGA. Scale bar: $11 \mu \mathrm{m}$. (c) DBA. Scale bar: $14 \mu \mathrm{m}$. (d) UEA-1. Scale bar: $17 \mu \mathrm{m}$. (e) RCA-1. Scale bar: $14 \mu \mathrm{m}$. (f) PNA. Scale bar: $13 \mu \mathrm{m}$. Glycocalyx-cilia (arrow), apical cytoplasm (arrowhead). 
(Glc), mannose (Man) and N- acetyl glucosamine (GlcNac) to form other classes of O-linked glycans (Desantis et al., 2006; Parillo et al., 2009). The oligosaccharides of the Nand O- chains of the GCs are involved in functions such as protection, signaling between cells and cell differentiation. In order to know the possible functional role of these GCs, it becomes essential to know their carbohydrate composition (Sáez et al. 2001, Desantis 2006, Parillo et al. 2009).

The glycocalyx is a cellular structure with a great number of functions assigned in different epithelia. An example of these functions is the brush border of the gut absorptive cells that act as a protective layer (Vallon-Eberhard et al. 2006). Reactivity to different types of lectins indicates the diversity and intricacy of the glycocalyx (Pajak \& Danguy 1993). In fishes, as well as in mammals, saccharide moieties identified in the glycocalyx may participate in the transport of macromolecules over the cell membrane (Arellano et al. 2001, Marchetti et al. 2006). In particular, the glycocalyx of the epithelium of the ovarian lamellae of $G$. blacodes strongly reacted with Con $A$, which indicates the presence of terminal, $\alpha$ - manosyl residues. Con-A, like other Man-binding lectins, was recently used to identify GCs containing $\mathrm{N}$ - linked oligosaccharides, since 0 - linked oligosaccharides contain less than 1\% Man (Spicer and Schulte 1992). Mannose is specific to serous cells in human bronchioles (Rogers et al. 1993). A Con- A binding protein that has been reported to protect fish against bacterial infection was determined in the skin mucus of carp (Lemaitre et al. 1996) and is considered to be secreted by a serous-type cell (Díaz et al. 2005). Similar functions could probably be inferred from the epithelium of the ovarian lamellae of $G$. blacodes.

The wheat germ agglutinin (WGA) is another lectin that strongly labels the glycocalyx and recognizes $\mathrm{N}$ - acetylglucosamine and sialic acid (acetylneuraminic acid). Cobo et al. (2004) suggested that the presence of GCs binding WGA is typical of cells that specialize in fluid and ion transport through membranes. WGA exhibits a strong affinity both to sialic acid at its terminal position and to $\beta$-D-GLcNAc residues located in an internal position (Díaz et al. 2005). In a previous work, using histochemical techniques to identify GCs, the authors described the presence of moderate quantities of sialic acid in the epithelium of the ovarian lamellae of $G$. blacodes (Freijo et al. 2009). It is assumed, therefore, that the positive reaction observed where samples were incubated with WGA could be due to sialic acid residues present in the glycocalix. Sialic acid has been found in a variety of fishes when using conventional histochemical methods and chemical analyses (Genten \& Danguy 1990). Sialic acid has been employed to determine the degree of skin mucification in different species. Thus, sialic acid could cause the fluidity and properties of mucus (Meyer et al. 2001). Furthermore, sialic acid residues are necessary for the GCs conformation, being the latter important for the correct ordering of GCs molecules in the cell membrane and also essential as a receptor component. Thus, the capacity of viruses and toxins to infect cells is exclusively dependent on the presence of sialic acids in the cell membranes (Pajak \& Danguy 1993, Díaz et al. 2005).

The epithelial glycocalyx of the ovarian lamellae of $G$. blacodes also possess 0-glycans with $\alpha$-D-GalNAc, $\beta$-DGalNAc, $\beta$-D-Gal $(\beta 1->3)$, D-GalNAc and $\beta$-Gal residues as evidenced by DBA, SBA, PNA and RCA1. O-linked oligosaccharides (mucin type glycans) are characteristic secretory moieties. It is remarkable that a major function of 0 -glycosylation is the gel-forming ability of mucins (Pajak \& Danguy 1993); it has been demonstrated in the digestive system of various teleosts that gel operates as a protective barrier for the under-lying mucose (Domeneghini et al. 1998, Desantis et al. 2009). Our results with Gal-binding lectins indicate that the epithelial glycocalyx of the ovarian lamellae possess Gal moieties. The existence of $\beta$-GalNAc is corroborated by the same staining pattern of both lectin DBA and SBA. These two lectins may be considered specific for GalNAc although DBA binds especially to a-GalNAc, whereas SBA does not evidence anomeric specificity. Moreover, N-Acetylgalactosamine sequences are present in the epithelium of the ovarian lamellae, and the galactose binding lectin RCA-I exhibit in these cells low staining intensity. In addition, the termed oligosaccharide Gal $(\beta 1>3)$ GalNAc terminal the T-antigen, is the specific binding site for PNA lectin (Saéz et al. 2000). It is suggestive that lectins binding galactose (PNA y RCA-1) as 0 -glycanes have demonstrated only weak reactions in the glycocalyx of the epithelium of the ovarian lamellae; lectins labeling can be masked by sulphate groups, being galactose the main residue, usually found sulphated in other reproductive tissues, taking part in the adhesion of gametes and the induction of the acrosome reaction (Parillo et al. 2000, 2001). Sulphate esters are important for increasing the biological efficiency of carbohydrates, taking part in the formation of an acidic and strongly negative environment which influences the mucus viscoelectricity. In a previous work, with techniques such as Alcian Blue at different $\mathrm{pH}$ 's, the authors determined the presence of sulphate groups in the glycocalyx of the epithelium of the ovarian lamellae, which are probably bound to galactose residues (Freijo et al. 2009). The galactosides have been involved in cell adhesion mechanisms of primordial germ cells (Alonso et al. 2001).

Lectin UEA-1 moderately bound to fucose in the epithelial glycocalyx of the ovarian lamellae. Fucose is usually an ordinary component of mucous cells of diverse teleosteans species as well as of the microvilli of secretory epithelia (Díaz et al. 2008). In particular, $\alpha$-L-fucose, further testified the important role of this sugar in morphogenetic processes of plasma membranes submitted to rapid turnover (Marchetti et al. 2006).

The cytoplasm of epithelial cells keeps a polarity in its carbohydrate composition: it is possible that GCs present in different sites could cooperate with the cell polarity maintenance, as reported for other organs (Gheri et al. 2001). This polarity is typical of the secretory function of epithelial cells. The lectin that demonstrated the greatest affinity for the apical cytoplasm was Con-A, thus showing the presence of mannose in this cell zone. It is well known that the $\mathrm{N}$-glycan synthesis of membrane and secretory proteins occur in the rough endoplasmic reticulum, being mannose the first added sugar as poly-Man chains (Kamer- 
ling \& Gerwig 2007).The extension of these chains occurs in the Golgi apparatus; the cytoplasmic labeling pattern of the epithelium of the ovarian lamellae is possibly an image of that synthesis path.

Concerning the rest of lectins, labelling in the apical cytoplasm evinced with SBA is weak, and no reaction with these lectins was observed in the entire basal cytoplasm. It is a well-known fact that some sugars can "hide" lectins through compression during synthesis in order to keep new components (Sáez et al. 2001). In this way, variability can result from addition or compression of new components. Small quantities of sialic acid or sulphated esters were found using histochemical methods, which could conceal lectins results.

Changes in the intensity of PNA and SBA binding in the epithelium of the ovarian lamellae of $G$. blacodes might express different degrees of terminal glycosylation, probably brought about a maturation stage or a functional status of the cell (Burkhard-Holm 1997).

In brief, observations by means of lectins support and enlarge the understanding about the structure and functionality of the epithelium of the ovarian lamellae of $G$. blacodes, and offer a useful tool to study this tissue in other teleosts species. Further studies will be necessary to complete our knowledge in this field.

\section{CONCLUSION}

Our study is a report that completes the detailed chemical structure of the GCs produced by the epithelium of the ovarian lamellae of Genypterus blacodes. Knowledge of the normal glycoprofile of the epithelium of the ovarian lamellae of $G$. blacodes may represent a basis for the study of this structure in other teleosts species.

Acknowledgments.- This study was supported by the Universidad Nacional de Mar del Plata (UNMDP).

\section{REFERENCES}

Alonso E., Sáez F.J., Madrid J.F. \& Hernández F. 2001. Galactosides and sialygalactosides in O-linked oligosaccharides of the primordial germ cells in Xenopus embryos. Glycoconjugate J. 18:225-230.

Arellano J.M., Storch V. \& Sarasquete C. 2001. A histological and histochemical study of the oesophagus and oesogaster of the Senegal sole, Solea senegalensis. Eur. J. Histochem. 45:279-294.

Arellano J.M., Storch V. \& Sarasquete C. 2004. Ultrastructural and histochemical study on gills and skin of the Senegal sole, Solea senegalensis. J. Appl. Ichthyol. 20:452-460.

Burkhardt-Holm P. 1997. Lectin histochemistry of rainbow trout (Oncorhynchus mykiss) gill and skin. Histochem J. 29:893-899.

Cobo E.R., Campero C.M., Gimeno E.J. \& Barbeito C.G. 2004. Lectin binding patterns and immunohistochemical antigen detection in the genitalia of Tritrichomonas foetus-infected Heifers. J. Comp. Pathol. 131:127-134.

Cousseau M.B. \& Perrotta R.G. 2000. Peces marinos de Argentina: biología, distribución, pesca. INIDEP, Mar del Plata. 167p.

Desantis S., Ventriglia G., Suban D., Deflorio M., Megalofonou P., Acone F., Zarrilli A., Palmieri G. \& De Metrio G. 2006. Histochemical analysis of glycoconjugates in the domestic cat testis. Histol. Histopathol. 21:11-22.

Desantis S., Acone F., Zizza S., Deflorio M., Palazón Fernández J.L., Sarasquete C. \& De Metrio G. 2009. Glycohistochemical study of the toadfish Halobatrachus didactylus (Scheider, 1801) stomach. Sci. Mar. 73:515525.
Díaz A.O., García A.M. \& Goldemberg A.L. 2005. Glycoconjugates in the branchial mucous cells of Cynoscion guatucupa (Cuvier, 1830) (Pisces: Sciaenidae). Sci. Mar. 69: 545-553.

Díaz A.O., García A.M. \& Goldemberg A.L. 2008. Glycoconjugates in the mucosa of the digestive tract of Cynoscion guatucupa: A histochemical study. Acta Histochem. 110:76-85.

Domeneghini C., Pannelli Straini R. \& Veggetti A. 1998. Gut glycoconjugates in Sparus aurata L. (Pisces, Teleostei). A comparative histochemical study in larval and adult ages. Histol. Histopathol. 13:359-372.

Freijo R.O., García A.M., Portiansky E.L., Barbeito C.G., Macchi G.J. \& Díaz A.0. 2009. Morphological and histochemical characteristics of the epithelium of ovarian lamellae of Genypterus blacodes (Schneider, 1801). Fish Physiol. Biochem. 35:359-367.

Genten F. \& Danguy A. 1990. A comparative histochemical analysis of glycoconjugates in secretory cells of fish epidermis by use of biotinylated lectins. Z. Mikrosk. Anat. Forsch. 104:835-855.

Gheri G., Noci I., Sgambati E., Borri P., Taddei G. \& Gheri Bryk S. 2001. Ageing of the human oviduct: lectin histochemistry. Histol. Histopathol. 16:21-28.

Gimeno E. J., Massone A.R., Marino F.P. \& Idiart J.R. 1995. Intermediate filament expression and lectin histochemical features of canine transmissible venereal tumour. APMIS 103:645-650.

Goldstein I.J. \& Hayes C.G. 1978. The lectins: carbohydrate binding proteins of plants and animals. Adv. Carbohydr. Chem. Biochem. 35:127-340.

Kamerling J.P. \& Gerwig G.J. 2007. Strategies for the structural analysis of carbohydrates, p.1-68. In: Kamerling J.P. (Ed.), Comprehensive Glycoscience, from Chemistry to Systems Biology. Vol.2. Elsevier Science, UK.

Koya Y., Munehara H. \& Takano K. 2002. Sperm storage and motility in the ovary of the marine sculpin Alcichthys alcicornis (Teleostei: Scorpaeniformes), with internal gametic association. J. Exp. Zool. 292:145-155.

Lahnsteiner F. 2007. First results on a relation between ovarian fluid and egg proteins of Salmo trutta and egg quality. Aquacult. Res. 38:131-139.

Lemaitre C., Orange N., Saglio P., Saint N., Gagnon J. \& Molle G. 1996. Characterization and ion channel activities of novel antibacterial proteins from the skin mucosa of carp (Cyprinus carpio). Eur. J. Biochem. 240:143-149.

Louge E.B., Villarino M.F., Martinez A.P. \& Christiansen H.E. 1992. Estructura macro y microscópica del ovario del abadejo en estados de reversión y crecimiento ovocitario. Bol. Inst. Esp. Oceanogr. 8:239-245.

Machinandiarena L., Villarino M.F. \& Macchi G.J. 1998. Descripción del estadio de desove del abadejo manchado Genypterus blacodes (Schneider, 1801) (Pisces, Ophidiidae) en el Mar Argentino. Bol. Inst. Esp. Oceanogr. 14:49-55.

Machinandiarena L., Villarino M.F., Cordo H., Macchi G.J. \& Pájaro M. 2003. Descripción macroscópica de los ovarios del abadejo manchado (Genypterus blacodes). Escala madurativa. Serie Inform. Téc. INIDEP no $56.8 \mathrm{p}$.

Mansour N., Lahnsteiner F. \& Patzner R.A. 2009. Ovarian fluid plays an essential role in attachment of Eurasian perch, Perca fluviatilis eggs. Theriogenology 71:586-593.

Marchetti L., Capacchietti M., Sabbieti M.G., Accili D., Materazzi G. \& Menghi G. 2006. Histology and carbohydrate histochemistry of the alimentary canal in the rainbow trout Oncorhynchus mykiss. J. Fish. Biol. 68:18081821.

Meyer W., Tsukise A., Neurand K. \& Hirabayashi Y. 2001. Cytological and lectin histochemical characterization of secretion production and secretion composition in the tubular glands of the canine anal sacs. Cell Tiss. Org. 168:203-219.

Mittal S., Pinky \& Mittal A.K. 2002. Characterisation of glycoproteins in the secretory cells in the operculum of an Indian hill stream fish Garra lamta (Hamilton) (Cyprinidae, Cypriniformes). Fish Physiol. Biochem. 26:275-288

Munehara H. 1989. Studies on the reproductive biology of the masked greenling, Hexagrammos octogramus. Ph.D. Thesis, Hokkaido University, Japan.

Pajak B. \& Danguy A. 1993. Characterization of sugar moieties and oligosaccharide sequences in the distal intestinal epithelium of the rainbow trout by means of lectin histochemistry. J. Fish Biol. 43:709-722. 
Parrillo F., Fagioli O., Dall' Aglio C. \& Verini Supplizi A. 2000. Lectin histochemical detection of sulfoglycans in the zona pellucida of mammalian antral oocytes. Acta Histochem. 102:193-202.

Parrillo F. \& Verini Supplizi A. 2001. Glycohistochemistry of the zona pellucida of developing oocytes in the rabbit and hare. Res. Vet. Sci. 70:257-264.

Parrillo F., Arias M.P. \& Verini Supplizi A. 2009. Glycoprofile of the different cell types present in the mucosa of the horse guttural pouches. Tissue Cell 41:257-265.

Rogers A.V., Dear A., Corrin B. \& Jeffrey P.K. 1993. Identification of serous-like cells in the surface epithelium of human bronchioles. Eur. Resp. J. 6:498-504.

Sáez F.G., Madrid J.F., Alonso E. \& Hernández F. 2000. Lectin histochemical identification of the carbohydrate moieties on $\mathrm{N}$ - and O- linked oligosaccharides in the duct cells of the testis of an amphibian urodel, the Spanish newt (Pleuronectes waltl). Histochem. J. 32:717-724.
Sáez F.G., Madrid J.F., Alonso E. \& Hernández F. 2001. Glycan composition of follicle (Sertoli) cells of the amphibian Pleurideles waltl: A lectin histochemical study. J. Anat. 198:673-681.

Spicer S.S. \& Schulte B.A. 1992. Diversity of cell glycoconjugates shown histochemically: a perspective. J. Histochem. Cytochem. 40:1-38.

Vallon-Eberhard A., Landsman L., Yogev N., Verrier B. \& Jung S. 2006. Transepithelial pathogen uptake into the small intestinal lamina propria. J. Immunol. 176:2465-2469.

Yoneda M., Tokimura M., Fujita H., Takeshita N., Matsuyama M. \& Matsuura S. 1998a. Ovarian structure and batch fecundity in Lophiomus setigerus. J. Fish Biol. 52:94-106.

Yoneda M., Tokimura M., Fujita H., Takeshita N., Matsuyama M. \& Matsuura S. 1998b. Reproductive cycle and sexual maturity of the anglerfish Lophiomus setigerus in the East China Sea with a note on specialized spermatogenesis. J. Fish Biol. 53:164-178. 